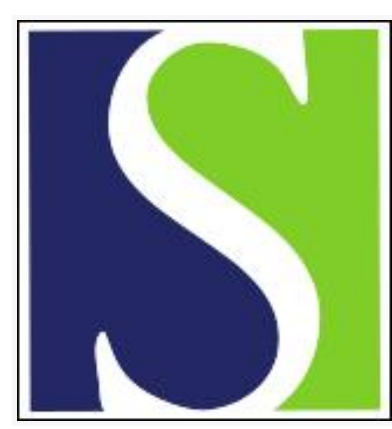

Scand J Work Environ Health 1998;24(2):104-108

https://doi.org/10.5271/sjweh.286

Issue date: Apr 1998

Prevalence of antibodies specific to Puumala virus among farmers in Sweden

by Ahlm C, Thelin A, Elgh F, Juto P, Stiernström E-L, Holmberg $S$, Tärnvik A

Key terms: farmer; hantavirus; hemorrhagic fever; occupational risk; seroepidemiology

This article in PubMed: www.ncbi.nlm.nih.gov/pubmed/9630057

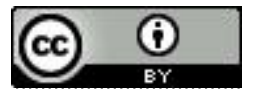




\title{
Prevalence of antibodies specific to Puumala virus among farmers in Sweden
}

\author{
by Clas Ahlm, MD, 1,2 Anders Thelin, PhD, ,3,4 Fredrik Elgh, PhD, 2,5 Per Juto, PhD, ${ }^{2}$ \\ Eva-Lena Stiernström, $M D,{ }^{6}$ Sara Holmberg, MD, ${ }^{6}$ Arne Tärnvik, PhDt
}

\begin{abstract}
Ahlm C, Thelin A, Elgh F, Juto P, Stiernström E-L, Holmberg S, Tärnvik A. Prevalence of antibodies specific to Puumala virus among farmers in Sweden. Scand J Work Environ Health 1998;24(2):104-8.
\end{abstract}

\begin{abstract}
Objectives The Puumala virus is the causative agent of nephropathia epidemica, a European form of hemorrhagic fever with a renal syndrome. From its reservoir in bank voles, the virus is spread by airborne transmission to humans. Occupational risks for the acquisition of nephropathia epidemica are not well defined. The prevalence of serum antibodies to Puumala virus was determined for Swedish farmers. From a comparison of the prevalence among farmers from various parts of the country, the assumption that Puumala virus occurs endemically only in the northern and central parts of Sweden was also tested.

Methods Serum samples from 910 farmers and 663 referents living in various rural parts of Sweden were tested with an enzyme-linked immunosorbent assay, using a recombinant nucleocapsid protein of Puumala virus as the antigen.

Results North of a latitude of $59^{\circ} \mathrm{N}$, the prevalence of Puumala virus antibodies was significantly higher among farmers $(12.9 \%)$ than among referents $(6.8 \%)$. In the southern areas, antibodies to Puumala virus were rare, and altogether only 2 of 459 persons had antibodies. Seropositive persons did not differ from seronegative ones with regard to blood pressure, and they did not comprise cases of chronic renal disease.

Conclusions Serological evidence confirmed that the exposure of humans to Puumala virus is firmly restricted to the northern and central parts of Sweden. In addition the evidence indicated that, in this region, farming is associated with an increased risk of contracting hantavirus infection.
\end{abstract}

Key terms hantavirus, farmers, hemorrhagic fever, occupational risk, seroepidemiology.

The genus Hantavirus of the family Bunyaviridae comprises several human pathogens. Hantaan, Seoul, Dobrava, and $\mathrm{Pu}-$ umala virus are serologically distinguishable hantaviruses and causative agents of hemorrhagic fever with renal syndrome. They occur endemically in rodent reservoirs, each being associated preferentially with a given rodent species (1). Hantaan and Dobrava viruses are endemic to Asia and the Balkan region, respectively, whereas Seoul virus, due to its association with the Norwegian rat, is believed to occur in various parts of the world $(1-3)$. Puumala virus is found in Europe, where its main reservoir is the bank vole (4). A newly described hantavirus is the Sin Nombre virus. The Sin
Nombre virus occurs in the United States, is associated with the deer mouse, and induces a disease called the hantavirus pulmonary syndrome (5). By serological testing with nucleocapsid protein as an antigen, cross-reactivity has been found among the Hantaan, Seoul and Dobrava viruses on one hand and between the Puumala and Sin Nombre viruses on the other (6).

In Scandinavia, Puumala virus is the only hantavirus known to occur endemically. It causes nephropathia epidemi$\mathrm{ca}$, a relatively mild form of hemorrhagic fever with renal syndrome $(7,8)$. Its symptoms are fever, malaise, headache, and back pain. Thrombocytopenia and renal failure with proclas.ahlm@infdis.umu.se]

Department of Infectious Diseases, University of Umeå, Umeå, Sweden.

Department of Virology, University of Umeå, Umeå, Sweden.

The Swedish Farmers' Safety and Preventive Health Association, Malmö, Sweden.

Department of Public Health Sciences, Division of Psychosocial Factors and Health, Karolinska Institute, Stockholm, Sweden.

Department of Microbiology, Division of NBC Defence, Defence Research Establishment, Umeå, Sweden. Department of Family Medicine, Uppsala University, Uppsala, Sweden.

Reprint requests to: Dr Clas Ahlm, Department of Infectious Diseases, Umeå University, S-901 85 Umeå, Sweden. [e-mail 
teinuria, oliguria, and markedly increased serum levels of creatinine are the most conspicuous findings. Recovery is usually complete.

In Sweden, nephropathia epidemica occurs endemically in a region north of a line connecting the western coast at a latitude of $59^{\circ} \mathrm{N}$ with the eastern coast at a latitude of $60^{\circ} \mathrm{N}$ $(9,10)$. In this region, the density of the bank vole population varies in cycles of $3-4$ years, and the incidence of nephropathia epidemica shows a covariation (11). In a randomized and stratified study from northern Sweden, a 9\% prevalence of Pumala virus antibodies was found for the adult population. Farmers and forestry workers had an increased prevalence $(12,13)$. It could not be discerned, however, whether the difference was due to occupation or to the workers' rural living only.

The objective of the present study was to determine a possible occupational risk of contracting hantavirus infection by comparing farmers with matched rural referents. Besides, the study afforded a critical test of the assumption that Puumala virus is restricted to northern and central Sweden. In this respect, farmers were supposed to be an ideal group for study due to their high putative exposure to the virus. A sensitive and specific hantavirus recombinant nucleocapsid protein in an enzyme-linked immunosorbent assay (ELISA) $(6,14)$ was used.

\section{Subjects and methods}

\section{Study subjects}

In 1990, a study cohort was created from farmers for studies of morbidity, health indicators, and health risks. By use of the Swedish register of farming and local information from the Swedish Farmers Association, all active male farmers (working at least $25 \mathrm{~h} /$ week), $40-60$ years of age and living in 9 selected municipalities were invited to participate (figure 1). Altogether 1221 farmers were invited. For every farmer, a referent was selected. The referents were randomly matched according to gender (only males), age (same age \pm 3 years), and place of living (same local area) with the aid of a central population register. All the referents were occupationally active but not in farming. Altogether 1130 subjects were included as referents. The study took place in 19901991 including examinations, interviews, and the completion of the questionnaires.

Blood was collected by venepuncture, and serum samples were stored at $-20^{\circ} \mathrm{C}$ until analyzed. Any history of previous diseases and visits to a hospital or health services were recorded. A self-reported history of renal disease was jointly evaluated by 3 physicians, using codes 580-591 and 593 of the International Classification of Diseases, 9 th revision, for definition. Blood pressure was measured by an automatic triple manchett after 5 minutes of rest in a lying position.
Of the 1221 farmers invited to participate in the study, $1013(83 \%)$ participated. In the reference group, $769(68 \%)$ of 1130 men participated. The mean age was 52 years for both the farmers and the referents. The project was approved by the Research Ethical Committee of the Karolinska Institute and the National Computer Data Inspection Board.

\section{Data processing and statistical analyses}

The data base $\mathrm{dBase} \mathrm{T}^{\mathrm{TM}}$ was used for the data processing, and statistical analyses were performed with the software program SPSS $^{\text {TM }}$ for Windows. The comparison of groups was made with the chi-square test, and multiple regression was used to compare various variables with respect to the presence of Puumala virus antibodies.

\section{Hantavirus recombinant nucleocapsid protein ELISA}

Microtiter plates (Maxisorp; NUNC, Roskilde, Denmark) were coated overnight at room temperature with $0.2 \mu \mathrm{g} /$ well of Escherichia coli expressed recombinant fusion proteins containing amino acids $1-117$ of the Hantaan, Seoul, Dobrava, Sin Nombre, and Puumala virus nucleocapsid proteins (6). Each of the 5 recombinant hantavirus antigens was diluted in carbonate buffer, $\mathrm{pH}$ 9.6. The plates were washed in deionized water and blocked with phosphate-buffered saline (PBS) containing $0.1 \%$ Tween $^{(B)} 20$ (polyoxyethylene sorbitan monolaurate) and $4 \%$ defatted milk powder for 30 minutes at room temperature. After washing in deionized water, $100 \mu \mathrm{l}$ of serum [diluted $1 / 100$ in PBS with $0.1 \%$ Tween $^{\boxplus} 20,2 \%$ defatted milk-powder, and $E$ coli antigen extract $(20 \mu \mathrm{g} / \mathrm{ml})]$ were added for incubation at $37^{\circ} \mathrm{C}$ for 1 hour. Each serum sample was tested in duplicate wells towards all 5 hantavirus antigens and in control wells containing no antigen. After

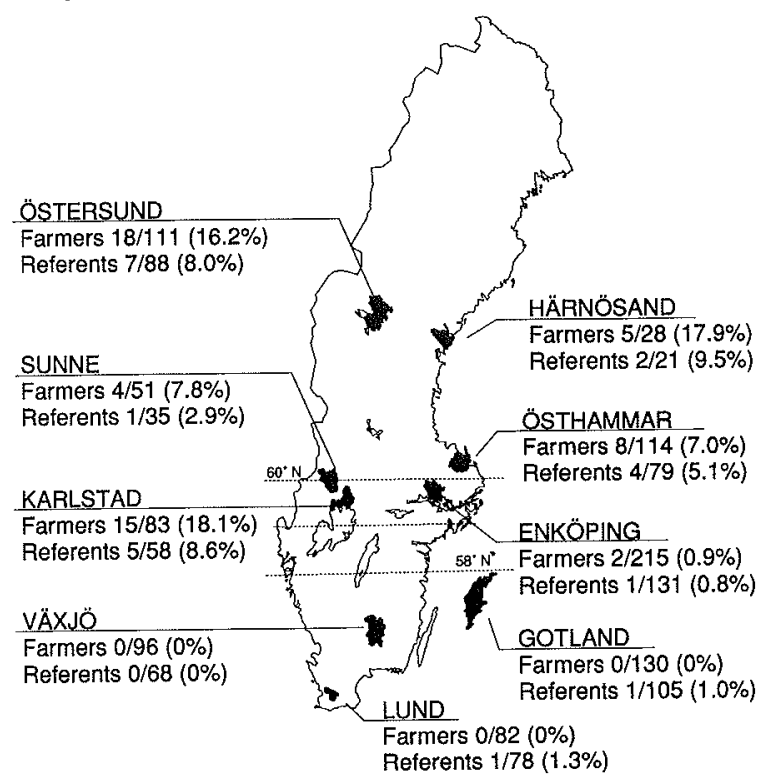

Figure 1. Seroprevalence to immunoglobulin $\mathrm{G}$ antibodies specific to Puumala virus among 910 farmers and 663 referents in 9 Swedish communities, a recombinant nucleocapsid protein-based ELISA being used for the determination. (ELISA $=$ enzyme-linked immunosorbent assay) 
4 washes in deionized water, goat antihuman immunoglobulin G conjugated with horseradish peroxidase (HRP) (A-6029, Sigma, St. Louis, MO, USA) at a dilution of $1 / 10000$ was added to each well, and the plates were incubated at $37^{\circ} \mathrm{C}$ for 1 hour. After 4 washes in deionized water and incubation for 15 minutes with $100 \mu 1$ of substrate (tetra-methylbenzidine, K-blue, ELISA Technologies, Lexington, KY, USA), the reaction was stopped with $50 \mu 1$ of $2 \mathrm{M}$ sulfuric acid. Antibody activity was expressed as the net absorbance value at $450 \mathrm{~nm}$ (mean absorbance of antigen-coated wells - mean absorbance of control wells). The upper net absorbance limit of nonimmune sera to the proteins was determined by use of sera from 150 Swedish children sent to our laboratory at the ages of $0-4$ years for gluten antibody testing. The mean absorbance value +3 SD of such sera was 0.055 . A net absorbance of $>0.15$ was considered to show the presence of specific antibodies to hantavirus nucleocapsid protein.

\section{Immunofluorescence assay}

All sera showing the presence of antibodies by the ELISA result were tested by an indirect immunofluorescence antibody assay (IFA) using Puumala virus (Sotkamo strain), Hantaan virus (strain 76-118), and Sin Nombre virus (strain CC107) propagated in Vero E6 cells. Sera were diluted 1/8 and incubated for 1 hour at room temperature. After washing with PBS-Tween, fluorescein-labeled rabbit anti-human IgG (F0202, Dako, Denmark) diluted 1/30 in PBS plus 0.003\% Evans blue was used as a conjugate. After incubation at $37^{\circ} \mathrm{C}$ for 1 hour, the samples were read blindly in a fluorescence microscope. Sera showing characteristic cytoplasmic fluorescence at a dilution of $1 / 8$ were considered to contain antibodies to the hantavirus.

\section{Results}

Out of 1573 subjects (910 farmers and 663 referents) available for analysis, 74 (4.7\%) had serum antibodies to Puumala virus as disclosed by the recombinant nucleocapsid protein ELISA. In 73 of these persons, the presence of antibodies to Puumala virus was confirmed also by IFA. In the region of northern and central Sweden endemic for nephropathia epidemica (figure 1), the prevalence of antibodies detectable by ELISA was significantly $(\mathrm{P}=0.010)$ higher among the farmers $(12.9 \%)$ than among the referents living in a rural area $(6.8 \%)$. It corresponded to a relative risk estimate of 2.05 for the farmers in relation to the referents [95\% confidence interval $(95 \% \mathrm{CI}) 1.17-3.55]$. The results were similar for all the selected areas of the endemic region (figure 1). In the southern nonendemic part of Sweden, only $2(0.4 \%)$ of 459 persons had antibodies in the ELISA results (figure 1). For the subjects from Enköping, situated on the border of the endemic area, the seroprevalence was $0.9 \%$ ( 3 of 346 persons).

The presence of Puumala virus antibodies did not significantly correlate with age $(\mathrm{P}=0.30)$. This finding is in contrast to the results of a previous investigation of a randomized and stratified adult population in which the seroprevalence was found to increase with age (12). It should be recalled, however, that our material comprised subjects of a relatively narrow age interval. The occurrence of serum antibodies to Puumala virus did not correlate with elevated systolic blood pressure ( $>150 \mathrm{~mm} \mathrm{Hg})(\mathrm{P}=0.43)$, and the systolic blood pressure of the seropositive persons did not differ $(\mathrm{P}=0.47)$ from that of the seronegative persons. Five of the 74 persons with antiPuumala virus antibodies reported a history of renal disease. For 4 of these persons, hospital records were available. One patient had undergone uncomplicated nephropathia epidemi$\mathrm{ca}$, whereas the diagnoses of the others were poststreptococcal glomerulonephritis, hydronephrosis with ureteral occlusion, and pyelonephritis with obstruction. Thus no case of chronic renal disease or renal sequelae was found to be associated with nephropathia epidemica among the subjects who had Puumala virus antibodies. As regards size of farm or set of animals, there was no difference among the seropositive $(\mathrm{N}=50)$ and seronegative farmers $(\mathrm{N}=337)$ in the endemic region.

Of the persons negative in the ELISA for Puumala virus antibodies, 10 subjects showed reactivity to the nucleocapsid protein of one or more other hantaviruses (table 1). This result was reproduced in repeated testing. Seven of these persons were from the nonendemic region or from the border region of the endemic region. Three showed reactivity to the Sin Nombre virus protein and 7 to proteins of the HantaanSeoul-Dobrava group. For serum from 2 of the 3 Sin Nombre virus positive sera and in 3 of the other 7 specimens, IFA confirmed the presence of antibodies to Sin Nombre and Hantaan virus, respectively (table 1). None of these 10 persons showed reactivity by IFA when Puumala virus was used as the antigen.

\section{Discussion}

In a previous study from northern Sweden, farmers and forestry workers showed an increased prevalence of antibodies to Puumala virus (12). It could, however, not be determined whether the difference was attributed to occupation or to rural living alone (12). In this study, we investigated large numbers of farmers and referents living in comparable areas and assessed the presence of an increased risk (relative risk 2.05) due to occupation per se.

Occupation risks for the acquisition of nephropathia epidemica are not well defined. In Germany and The Netherlands, Puumala virus antibodies have been found in increased frequency in animal trappers, forestry workers, and horse farmers $(15,16)$ although not in farmers in general $(16)$. Compared with the results of our study, however, these data were collected from very few seropositive subjects. In China, an increased incidence of hemorrhagic fever with renal syn- 
Table 1. Patterns of reactivity in enzyme-linked immunosorbent assay (ELISA) and immunofluorescence assay (IFA) of sera repeatedly reactive to recombinant nucleocapsid proteins of hantavirus other than PUU $(\mathbb{N}=10)$. (ND = not done)

\begin{tabular}{|c|c|c|c|c|c|c|c|c|c|}
\hline \multirow[t]{2}{*}{ Subject } & \multirow[t]{2}{*}{ Location } & \multicolumn{5}{|c|}{ ELISAa } & \multicolumn{3}{|c|}{$\mathrm{IFA}^{\mathrm{b}}$} \\
\hline & & HTN & SEO & $\mathrm{DOB}$ & SNV & PUU & HTN & SNV & PUU \\
\hline 1 (farmer) & Enköping & $0.00^{\circ}$ & 0.00 & 0.00 & 0.28 & 0.02 & $<8$ & $<8$ & $<8$ \\
\hline 2 (farmer) & Enköping & 0.03 & 0.02 & 0.00 & 0.70 & 0.01 & $<8$ & 8 & $<8$ \\
\hline 3 (farmer) & Enköping & 0.01 & 0.03 & 0.00 & 0.35 & 0.00 & $<8$ & 16 & $<8$ \\
\hline 4 (farmer) & Enköping & 0.26 & 0.21 & 0.07 & 0.01 & 0.03 & $<8$ & ND & $<8$ \\
\hline 5 (farmer) & Östhammar & 0.33 & 0.29 & 0.25 & 0.01 & 0.02 & 8 & ND & $<8$ \\
\hline 6 (farmer) & Östhammar & 0.19 & 0.10 & 0.25 & 0.02 & 0.00 & $<8$ & ND & $<8$ \\
\hline 7 (farmer) & Gotland & 0.24 & 0.16 & 0.17 & 0.00 & 0.00 & 8 & ND & $<8$ \\
\hline 8 (farmer) & Sunne & 0.23 & 0.00 & 0.23 & 0.01 & 0.01 & $<8$ & ND & $<8$ \\
\hline 9 (farmer) & Östersund & 0.27 & 0.13 & 0.08 & 0.01 & 0.00 & 32 & ND & $<8$ \\
\hline 10 (referent) & Växijö & 0.02 & 0.15 & 0.23 & 0.01 & 0.02 & $<8$ & ND & $<8$ \\
\hline
\end{tabular}

a ELISA using recombinant nucleocapsid protein of Hantaan (HTN), Seoul (SEO), Dobrava (DOB), Sin Nombre (SNV) or Puumala (PUU) virus (serum dilution $1 / 100)$.

- IFA using cells infected with Hantaan, Sin Nombre or Puumala virus. The figures indicate reciprocal titer values.

c Net absorbance value at $450 \mathrm{~nm}$.

drome was reported for residents engaged in heavy farm work (17). In Korea, telephone company employees working outdoors were found to be at increased risk (18). Thus an increased risk of contracting infection with Puumala virus and other hantaviruses seems to be attributed to occupation and not only to living in rural areas. This conclusion is in accordance with data on other zoonoses $(19,20)$.

Due to the frequent occurrence of conspicuous renal failure in the acute phase of hemorrhagic fever with renal syndrome, a possible relation between passed hantavirus infection and the occurrence of chronic renal disease is of interest. Although some circumstantial evidence suggesting such an association has been presented (21-24), a study of 792 persons living in Sweden within an area endemic for nephropathia epidemica showed no difference between seropositive and seronegative persons in several parameters linked to renal dysfunction (25). Moreover, none of 62 patients showed renal sequelae in the follow-up 2 - 6 years after nephropathia epidemica (25), and, of 66 patients with nephropathia epidemica followed for 6 months after discharge from the hospital, none developed chronically impaired renal function (26). In agreement with these reports, our study showed no significant association between hypertension and the occurrence of antibodies to Puumala virus, and the results of the self-reports, and an analysis of hospital records, presented no evidence of chronic renal disease associated with nephropathia epidemica within the group of seropositive persons. Altogether, there is no firm evidence at present to suggest an association between nephropathia epidemica and chronic renal disease.

The present demonstration of antibodies to hantaviruses other than Puumala virus in a few persons is not easily interpreted since, in Scandinavia, Puumala virus is the only hantavirus that has been identified so far. Antibodies to recombinant nucleocapsid proteins from the Hantaan-Seoul-Dobrava group have recently been found also in a small number of persons in a stratified and randomized material from the region (13). Moreover, that material also included persons reacting exclusively with the Sin Nombre protein. Although it cannot be excluded that these antibodies were due to irrelevant cross-reactivities, they do obviously merit increased awareness of the possibility that hantaviruses other than the Puumala virus may occur in the region.

Our study afforded a real test of the assumption that Puumala virus infection is restricted to the northern and central parts of Sweden. Various circumstances made the study especially designed for this purpose. First, the sensitivity of the recombinant protein based ELISA is high (14). Moreover, antibodies to Puumala virus endure for decades after the infection is contracted $(27,28)$; therefore serological investigation should have detected most of the persons affected irrespective of time lapse after infection. Finally, we selected a group of subjects shown to be at high risk of infection. Nevertheless, only 2 of the 459 subjects from the southern areas showed antibodies. Together with previous information from southern Sweden, including a rarity of clinical reports of nephropathia epidemica $(9,10)$, a very low seroprevalence $(<1 \%)$ among people seeking medical advice for nonspecified conditions, and a virtual lack of anti-Puumala virus antibodies among tested bank voles (9), the present data strongly indicate that the occurrence of the virus is geographically restricted and that the risk of exposure to Puumala virus in southern Sweden is virtually absent. It is true that, in a study of United Nations personnel, a seroprevalence of $2.4 \%$ was found for persons from southern Sweden but, as discussed by the authors, persons of such a category might have moved within Sweden and visited endemic regions more often than persons in the other categories tested (29).

In conclusion, our results strongly support the assumption that, in spite of the wide distribution of its host reservoir, Puumala virus is exposed to humans only in the central and northern parts of Sweden. In this endemic region, farming was defined as a risk occupation for contracting Puumala virus infection. No evidence of an impact of nephropathia epidemica on long-term health was found. The latter conclusion congrues with the results of several studies showing that farmers, in spite of occupation-related diseases, generally have a low morbidity and mortality $(30-32)$. 


\section{Acknowledgments}

Ann-Christin Verlemyr is gratefully acknowledged for her technical assistance. The slides with Sin Nombre virus were kindly provided by Åke Lundkvist.

The study was supported by grants from the Centre for Environmental Research, the Swedish Medical Research Council (B93-16X-10382,27X-07192), the Swedish Society of Medicine, the Joint Committee of the Northern Health Care Region, the Kempe Foundations, Förenade Liv Mutual Grouplife Insurance Company, and the Medical Faculty of Umeå University.

\section{References}

1. Lee HW, Lee PW, Baek LJ, Chu YK. Geographical distribution of hemorrhagic fever with renal syndrome and hantavinuses. Arch Virol 1990;suppl 1:5-18.

2. Schmaljohn CS, Hasty SE, Dalrymple JM, LeDuc JW, von Bonsdorff $\mathrm{C}-\mathrm{H}$, Brummer-Korvenkontio M, et al. Antigenic and genetic properties of viruses linked to hemorrhagic fever with renal syndrome. Science 1985;227:1041-4.

3. Avsic-Zupanc T, Xiao S-H, Stojanovic R, Gligic A, van der Groen G, LeDuc JW. Characterization of Dobrava virus: a Hantavirus from Slovenia, Yugoslavia. J Med Virol 1992;38:132-7.

4. Brummer-Korvenkontio M, Henttonen H, Vaheri A. Hemorrhagic fever with renal syndrome in Finland: ecology and virology of Nephropathia Epidemica. Scand J Infect Dis 1982;suppl 36:8891.

5. Nichol ST, Spiropoulou CF, Morzunov S, Rollin PE, Ksiazek TG, Feldmann $\mathrm{H}$, et al. Genetic identification of a hantavirus associated with an outbreak of acute respiratory illness. Science 1993;262; $914-7$.

6. Elgh F, Lundkvist Å, Alexeyev O, Stenlund H, Avsic-Zupanc T, Hjelle $B$, et al. Serological diagnosis of hantavirus infections by an enzyme-linked immunosorbent assay based on detection of immunoglobulin $\mathrm{G}$ and $\mathrm{M}$ responses to recombinant nucleocapsid proteins of five viral serotypes. J Clin Microbiol 1997;35:1122-30.

7. Lähdevirta J. Nephropathia epidemica in Finland: a clinical, histological and epidemiological study. Ann Clin Res 1971;3 suppl $8: 1-154$.

8. Settergren B, Juto P, Trollfors B, Wadell G, Norrby S. Clinical characteristics of Nephropathia epidemica in Sweden: prospective study of 74 cases. Rev Infect Dis 1989;11:921-7.

9. Niklasson B, LeDuc J. Epidemiology of nephropathia epidemica in Sweden. J Infect Dis 1987;155:269—-76

10. Settergren B, Juto P, Wadell G. Incidence and geographic distribution of serologically verified cases of nephropathia epidemica in Sweden. Am J Epidemiol 1988;127:801-7.

11. Niklasson B, Hörnfeldt B, Lundkvist A, Björsten S, Leduc J. Temporal dynamics of Puumala virus antibody prevalence in voles and of nephropathia epidemica incidence in humans. Am J Trop Med Hyg 1995;53:134-40.

12. Ahlm C, Linderholm M, Juto P, Stegmayr B, Settergren B. Prevalence of serum IgG antibodies to Puumala virus (haemorrhagic fever with renal syndrome) in Northern Sweden. Epidemiol Infect 1994;113:129-36.

13. Ahlm C, Juto P, Stegmayr B, Settergren B, Wadell G, Tärnvik A, et al. Prevalence of serum antibodies to hantaviruses in northern Sweden as measured by recombinant nucleocapsid proteins. Scand J Infect Dis 1997;29:349—54.
14. Elgh F, Linderholm M, Wadell G, Juto P. The clinical usefulness of a Puumalavirus recombinant nucleocapsid protein based enzymelinked immunosorbent assay in the diagnosis of nephropathia epidemica as compared with an immunofluorescence assay. Clin Diagn Virol 1996;6:17-26.

15. Zöller L, Faulde M, Meisel H, Ruh B, Kimmig P, Schelling U, et al. Seroprevalence of hantavirus antibodies in Germany as determined by a new recombinant enzyme immunoassay. Eur J Clin Microbiol Infect Dis 1995; 14:305-13.

16. Groen J, Gerding MN, Jordans JG, Clement JP, Nieuwenhuijs JH, Osterhaus $\mathrm{AD}$. Hantavirus infections in The Netherlands: epidemiology and disease. Epidemiol Infect 1995;114:373_-. 83.

17. Xu Z-Y, Guo C-S, Wu Y-L, Zhang X-W, Liu K. Epidemiological studies of hemorrhagic fever with renal syndrome: analysis of risk factors and mode of transmission. J Infect Dis 1985;152:137-44.

18. Lee HW, Bonwit C. Hemorrhagic fever - an occupational risk for OSP technicians? WHO Collaborating Centre for Virus Reference and Research (Haemorrhagic fever with renal syndrome). Seoul (Korea): Korea University, The Institute of Viral Diseases, 1991.

19. Stanford CF, Connolly JH, Ellis WA, Smyth ETM, Coyle PV, Montgomery WI, et al. Zoonotic infections in Northern Ireland farmers. Epidemiol Infect 1990;105:565-70.

20. Moll van Charante AW, Groen J, Osterhaus AD. Risk of infections transmitted by arthropods and rodents in forestry workers. Eur $\mathrm{J}$ Epidemiol 1994;10:349-51.

21. Kleinknecht D, Rollin PE. Hypertension after hemorthagic fever with renal syndrome. Nephron 1992;61:121.

22. Glass G, Watson A, LeDuc J, Kelen G, Quinn T, Childs J. Infection with a ratborne hantavirus in US residents is consistently associated with hypertensive renal disease. J Infect Dis 1993;167:614 - 20 .

23. Tsianos E, Dalekos G, Elisaf M, Zervou E, Siamopoulos K. High frequency of antibodies to Hantaan virus and hepatitis $\mathrm{C}$ virus in chronic haemodialysis patients: coincidence or cross-reaction? J Intem Med 1993;234:607-10.

24. Elisaf M, Korakis $\mathrm{H}$, Siamopoulos $\mathrm{K}$. Chronic renal dysfunction in hemorrhagic fever with renal syndrome patients. Ren Fail 1993; 15:623-7.

25. Niklasson B, Hellsten G, LeDuc J. Hemorrhagic fever with renal syndrome: a study of sequelae following nephropathia epidemica. Arch Virol 1994;137:241-7.

26. Settergren B, Trollfors B, Fasth A, Hultberg B, Norrby S. Glomerular filtration rate and tubular involvement during acute disease and convalescence in patients with nephropathia epidemica. J Infect Dis $1990 ; 161: 716-20$

27. Niklasson $B$, Tkachenko E, Ivanov AP, van der Groen G, Wiger D, Andersen $\mathrm{HK}$, et al. Haemornhagic fever with renal syndrome: evaluation of ELISA for detection of Puumala-virus-specific IgG and IgM. Res Virol 1990;141:637-48.

28. Settergren B, Ahlm C, Juto P, Niklasson B. Specific Puumala virus IgG half a century after haemorrhagic fever with renal syndrome. Lancet 1991;2:338.

29. Niklasson B, Nyman L, Linde A, Grandien M, Dalrymple J. An epidemiological survey of nephropathia epidemica in Sweden. Scand J Infect Dis 1983;15:239-45.

30. Gallagher R, Threlfall W, Spinelli J, Band P. Occupational mortality patterns among British Colombia farm workers. J Occup Med $1984 ; 26: 906-8$

31. Notkola VJ, Husman KRH, Laukkanen VJ. Mortality among male farmers in Finland during 1979-1983. Scand J Work Environ Health 1987;13:124-8.

32. Thelin A. Morbidity in Swedish farmers, 1978 - 1983, according to national hospital records. Soc Sci Med 1991;32:305-9.

Received for publication: 13 June 1997 